against : fortunately the difficulty is not great; a canopy composed of any light compact material closely attached to a wooden frame in whose outer margins glass cylinders are so far imbedded as to leave a bold, convex, exterior surface, would completely answer the purpose. This canopy, whose area must exceed that of the bed, may be supported on the summits of the bedposts or suspended from the ceiling, as may be most convenient ; and if its periphery were constructed without angles, it would be a decided advantage. When the extreme difficulty of extirpating bugs from rooms, especially in old houses where they have been suffered to multiply to excess, is borne in mind, the desirableness of possessing the means of securing beds from their insidious approaches will scarcely be denied.

The plan of protection against the attacks of the bed-bug which I have proposed or advocated, if the latter term should be thought more appropriate, of course was never intended to apply to animals provided with wings or a spinning apparatus; to prevent their access to beds, recourse must be had to musquito-curtains, or to some similar contrivance; but with regard to spiders, as they do not seek to prey upon or even to come in contact with the human species, and as the pain consequent upon the wounds which our more powerful indigenous species are capable of inflicting is very slight and speedily subsides, there is nothing to be apprehended from the Araneidea of Great Britain.

I am, my dear Sir, very truly yours, John Blackwall.

\title{
Description of Sarcoptilus, a new genus of Pennatulide.
} By J. E. Gray, Esq., F.R.S. etc.

Sir William Jackson Hooker lately sent to the British Museum some bottles containing animals in spirits, some from New Zealand, others from South America, and some without any habitats : amongst the latter there is a fine specimen of a Sea Pen, resembling the true genus Pennatula in general form, but differing from it most essentially in the form of the pinnce and their substance, and presenting a most interesting new form in the family.

Each of the pinnce resemble the frond of Renilla, Lam.; they are placed in two crowded rows, one on each side of the upper part of the axis, and, like that genus, they have the polypes scattered over the upper surface of the pinnæ, which, as well as the surface of the stem, do not exhibit any spicula, but are smooth and fleshy.

This genus may be considered as the passage between Pennatula and Renilla.

SARCoptilus.

Coral pen-shaped; shaft thick, fleshy, attenuated towards the tip, smooth, slightly striated longitudinally, and granulose on the surface; axis subquadrangular, rather thick, flexible when moist, formed of concentric coats and longitudinal fibres. Pinnce placed in two crowded rows, one on each side of one of the faces of the upper part 
of the shaft, kidney-shaped, crumpled, with the polypes scattered on the edge and upper surfaces, especially near the edge. Polypes small, when contracted leaving very small papillæ on the surface.

SARCOPTILUS GRANDIS.

Shaft very thick at the base, longitudinally striated. Pinnæ 25 on each side, the lower one smallest.

Hab. —? Brit. Mus.

Length 8 inches.-From the Proceedings of the Zool. Soc. for March 14, 1848.

Remarkable Instances of Instinct, or Intelligence, in Animals. By Dr. Warwick.

When he resided at Durham, the seat of the Earl of Stamford and Warrington, he was walking one evening in the park, and came to a pond, where fish intended for the table were temporarily kept. He took particular notice of a fine pike, of about six pounds weight, which, when it observed him, darted hastily away. In so doing, it struck its head against a tenterhook in a post (of which there were several in the pond, placed to prevent poaching), and, as it afterwards appeared, fractured its skull, and turned the optic nerve on one side. The agony evinced by the animal appeared most horrible. It rushed to the bottom, and, boring its head into the mud, whirled itself round with such velocity that it was almost lost to the sight for a short interval. It then plunged about the pond, and at length threw itself completely out of the water on to the bank. He (the doctor) went and examined it, and found that a very small portion of the brain was protruding from the fracture in the skull. He carefully replaced this, and, with a small silver tooth-pick, raised the indented portion of the skull. The fish remained still for a short time, and he then put it again into the pond. It appeared at first a good deal relieved, but in a few minutes it again darted and plunged about until it threw itself out of the water a second time. A second time Dr. Warwick did what he could to relieve it, and again put it into the water. It continued for several times to throw itself out of the pond, and, with the assistance of the keeper, the doctor at length made a kind of pillow for the fish, which was then left in the pond to its fate. Upon making his appearance at the pond on the following morning, the pike came towards him to the edge of the water, and actually laid its head upon his foot. The doctor thought this most extraordinary, but he examined the fish's skull, and found it going on all right. He then walked backwards and forwards along the edge of the pond for some time, and the fish continued to swim up and down, turning whenever he turned; but being blind on the wounded side of its skull, it always appeared agitated when it had that side towards the bank, as it could not then see its benefactor. On the next day he took some young friends down to see the fish, which came to him as usual, and, at length, he actually taught the pike to come to him at his whistle and feed out of his hands. With other persons it continued 


\section{$2 \mathrm{BHL}$ Biodiversity Heritage Library}

Gray, John Edward. 1849. "Description of Sarcoptilus, a new genus of Pennatulidæ." The Annals and magazine of natural history; zoology, botany, and geology 3, 76-77. https://doi.org/10.1080/03745485909494596.

View This Item Online: https://www.biodiversitylibrary.org/item/71826

DOI: https://doi.org/10.1080/03745485909494596

Permalink: https://www.biodiversitylibrary.org/partpdf/60244

\section{Holding Institution}

University of Toronto - Gerstein Science Information Centre

\section{Sponsored by}

University of Toronto

\section{Copyright \& Reuse}

Copyright Status: NOT_IN_COPYRIGHT

This document was created from content at the Biodiversity Heritage Library, the world's largest open access digital library for biodiversity literature and archives. Visit BHL at https://www.biodiversitylibrary.org. 